\title{
Impacts of aerosols of oxidized and reduced nitrogen along with light regime, physiological drought and substratum types on wheat (Triticum aestivum L.) crop
}

\author{
Bhagawan Bharali, Sonbeer Chack \\ Department of Crop Physiology, India
}

Correspondence: Bhagawan Bharali,Assam Agricultural University, Jorhat-7850।3,Assam, India, Email bbharali33@rocketmail.com, bbharali@aau.ac.in

Received: January 29, 2018 | Published: March 14, 2018

Copyright@ 2018 Bharali et al. This is an open access article distributed under the terms of the Creative Commons Attribution License, which permits unrestricted use, distribution, and reproduction in any medium, provided the original author and source are credited.

\section{Summary}

The main objective of the the investigation was to study the impacts of some abiotic factors on the responses of Ankur Omkar variety, wheat crop to oxidised (NaNO2) and reduced $(\mathrm{NH} 4 \mathrm{Cl})$ aerosols in field situation. Natural light was reduced to $\approx 50 \%$ using standard hessian cloth, and physiological drought was induced by spraying PEG-6000@5000ppm ( 00.05 bar). Substratum types were natural acid soil with FYM @5 t/ha (pH 5.03), acid-mineral soil (natural acid soil with FYM@10 t/ha, pH between 5.92) and acid-mineral soil mixed with FYM@10 t/ha added with lime@0.5t/ha (pH 6.46).There were positive effects of the aerosols on wheat crop under normal light condition, and low light suppressed the nitrogen assimilation and physiological performance of wheat. During the physiological drought condition, the aerosols showed negative impacts on wheat crop. The reduced aerosol acted as an acidifying agent, which was deleterious to the crop. Soil amended with higher dose (10t/ha) of FYM further exerted negative influence to the crop. Acid soil amended with lime (supply of Ca2+) can ameliorate the negative impacts of aerosols on yield attributes of wheat crop.

Keywords: wheat crop, aerosols, drought, harvest index, light, nitrogen, proline, RWC, substratum

\section{Introduction}

Atmospheric wet and dry depositions of Nitrogen are important processes in the redistribution of nitrogen throughout the environment. Nitrogen oxides $\left(\mathrm{NO}_{2}, \mathrm{NO}\right.$ but not $\left.\mathrm{N}_{2} \mathrm{O}\right)$ reacting with intercellular water get converted into $\mathrm{HNO}_{2}$ and $\mathrm{HNO}_{3}$, which then dissociate to form nitrate, nitrite and protons. ${ }^{1} \quad$ Reduction of nitrate and incorporation of reduced nitrogen into a wide range of compounds are found in nearly all higher plants. ${ }^{2}$ Higher concentration $(<10 \mu l 1$ $\left.{ }^{1}\right)$ of oxides of nitrogen alter the physiological processes including net photosynthesis, dark respiration, and root:shoot ratio in plants and yields. ${ }^{3}$ Cellular plasmolysis is caused by the lipid breakdown in membrane. ${ }^{4}$

Acidification of the ecosystem may also result from the deposition of gaseous $\mathrm{NH}_{3}$ and particulate $\mathrm{NH}_{4}{ }^{+}$(collectively $\mathrm{NH}_{\mathrm{y}}$ ) ${ }^{5,6}$ Plants fed with ammonia at high concentration $(>1 \mathrm{mM})$ suffer from its toxicity. Ammonia as an atmospheric pollutant can contribute to a substantial portion of total deposition of nitrogen. ${ }^{8}$ At high concentration $(>1 \mathrm{mM})$ ammonia is toxic to plants because feeding ammonia to roots or leaf fumigation results in yellowing of leaves, necrosis, and reduced growth or severe cases death of tissues. Ammonia may uncouple the chloroplast electron transport chain at $2.5 \mathrm{mM}$ concentration. ${ }^{9}$ The direct effects of ammonia assimilation on plants are (i) a decrease in nitrate assimilation by the root brought about by inhibition of its uptake, and inhibition of nitrate reductase, ${ }^{10}$ (ii) a reduction in cations (viz., $\mathrm{Ca}^{2+}, \mathrm{Mg}^{2+} \mathrm{K}^{+}$) uptake in tissues, and (iii) an increase in anion (viz., $\mathrm{PO}_{4}^{2-}, \mathrm{Cl}^{-}, \mathrm{SO}_{4}^{2-}$ ) content in tissues. ${ }^{11}$ Overall, the consequences of foliar uptake of ammonia result in alteration of competitive ability of plants for eutrophication or fertilization, but also impair physiological stability in susceptible species.

Light, a critical natural resource, especially controls morphogenesis and production in crop plants. Its intensity has a paramount role to play in the differentiation of auxiliary meristem in the plant. It has been established that solar radiation from primordial initiation to harvest in rice is essential as the sink size (spikelet number) is regulated by the light intensity before flowering and its proper filling by the incident light after flowering. ${ }^{12}$ On the other hand, drought stress also is involved with many biochemical, molecular, and physiological changes that influence various cellular and whole plant processes, and reduce quality and quantity of yield. ${ }^{13}$ Information on the responses of wheat crop to aerosols under reduced light and drought conditions are lacking.

Soil cations ameliorate susceptibility of plants to dissolved sulphur dioxide i.e bisulphite. ${ }^{14}$ In plant cells, extracellular calcium and iron 
from calcareous and acid mineral soils respectively alter physiology of in plants. ${ }^{15-17}$ The aberration brought out by the oxidised and reduced nitrogen in plants is instantaneous. ${ }^{18,19}$ How the ions derived from the various substrata do react to the nitrogenous aerosol in wheat crop is less understood. The roles of substratum with variations of $\mathrm{pH}$ on modulation of physiological responses of wheat crop to oxidised and reduced aerosols viz., $\mathrm{NaNO}_{2}$ and $\mathrm{NH}_{4} \mathrm{Cl}$ have been illustrated and discussed in this paper.

\section{Materials and methods}

Experiment 1. Effects of light stress on the Ankur Omkar variety of wheat crop were studied in a field experiment laid in split plot design. The main plot consisted of light regimes i.e. normal light and reduced light. The normal light was reduced $(\approx 50 \%)$ by using hessian cloth erected by bamboo frame one meter above the ground. The sub-plot comprised of the aerosols of nitrogen viz., $\mathrm{NH}_{4} \mathrm{Cl}(400 \mathrm{ppm})$ and $\mathrm{NaNO}_{2}(400 \mathrm{ppm})$ against a control (Distilled water). Light intensity below and above canopies using Lux meter (York Scientific Industries, YORCO), and Specific leaf weight ${ }^{20}$ were determined at 60 days crop growth. The light intensity readings (Lux) were converted into $\mu \mathrm{ES}$ ${ }^{1} \mathrm{~m}^{-2} .{ }^{21,22}$ Economic yield, biological yield, Test weight (1000 grain weight) and grain sugar ${ }^{23}$ were recorded at harvest.

Experiment 2. Effects of physiological draught (desiccation) were studied on field grown Ankur Omkar of wheat crop. The experiment was laid in split plot design. Water regimes (physiological drought and normal irrigation) were in the main plot. Desiccation in plant was induced by misting PEG-6000 solution $(5000 \mathrm{ppm} \approx$ at 0.05 bar). It was sprayed one week prior to the application of the nitrogenous aerosols at 60 days crop stand. The sub-plot comprised of the aerosols of nitrogen viz., $\mathrm{NH}_{4} \mathrm{Cl}(400 \mathrm{ppm})$ and $\mathrm{NaNO}_{2}(400 \mathrm{ppm})$ against a control (Distilled water). The indices for the study were RLWC ${ }^{24}$, Proline content in leaf ${ }^{25}, 1000$ grain weight and Harvest index.
Experiment 3. Investigation into the effects of substratum type and $\mathrm{N}$-aerosols on wheat Ankur Omkar variety was carried out in field condition. In a split plot design, the main plot comprised of different substratum viz., (a) natural acid soil with FYM @ 5 t/ha (pH 5.03), (b) acid-mineral soil (natural acid soil with FYM@10 t/ha, pH between 5.92) and (c) acid-mineral soil mixed with FYM @10 t/ha added with lime@0.5t/ha or more to raise soil pH 6.46). Initial soil pH was 2.72. The sub-plot comprised of nitrogen aerosols $\mathrm{NaNO}_{2} @$, 400ppm and $\mathrm{NH}_{4} \mathrm{Cl} @ 400 \mathrm{ppm}$ along with a control (double distilled water only). The observations comprised of 'Soil pH' in different experimental plots, effective tillers $/ \mathrm{m}^{2}$, (flower bearing tillers, spikelet number $/ \mathrm{m}^{2}$, HI: harvest index and spike weights.

Statistical analysis: Data were analysed following Generalised Linear Model (GLIM) program of Royal Society of London. ${ }^{26}$ Significant differences between two mean values due to treatments or varieties and their interaction at a crop growth stage were computed by comparing their significant levels at $\mathrm{P}<0.05$.

\section{Results and discussion}

In the preceding paper, we discussed about the susceptibility of wheat crop varieties to oxidised and reduced aerosols in terms of dose responses, phase sensitivity and mechanisms of action of aerosols on wheat ${ }^{18}$ as well as rice ${ }^{19}$ crops. The thrusts on how do the nitrogenous aerosols interact with the abiotic factors viz., light regimes and physiological drought, and role of substrata modulating the responses of wheat crop to the aerosols were studied separately in field, and the results of these experiments have been discussed in this manuscript.

In the first experiment, photon flux density (PPFD) differed significantly between two regimes of light. Reduction of light intensity was about $50 \%$ under shade condition than the normal situation. Light energy above canopy level was significantly higher (up to 33\%) than the below canopy irrespective of aerosol treatments (Table 1).

Table I Variation of PPFD $\left(\mu \mathrm{E} \mathrm{s}^{-1} \mathrm{~m}^{-1}\right)$ at Ankur Omkar variety of wheat crop canopy level

\begin{tabular}{lllllll}
\hline Light regimes & \multicolumn{2}{c}{ Normal light $(\mathrm{NL})$} & \multicolumn{3}{l}{ Shade $(\mathrm{S})(\approx 50 \%$ of NL) } \\
\hline x N-Aerosols & Below canopy & Above canopy & $\begin{array}{l}\text { Total incident } \\
\text { energy }\end{array}$ & Below canopy & Above canopy & $\begin{array}{l}\text { Total incident } \\
\text { energy }\end{array}$ \\
Oppm Aerosols (Distilled water) & 4133 & 9800 & 13933 & 1367 & 1700 & 3067 \\
$400 \mathrm{ppm} \mathrm{NH} \mathrm{Cl}$ & 5067 & 8467 & 13534 & 834 & 1000 & 1834 \\
$400 \mathrm{ppm} \mathrm{NaNO}$ & 5300 & 7133 & 12433 & 767 & 1367 & 2134 \\
\hline
\end{tabular}

Source: Field Experiment, 2012 at Assam Agricultural University, Jorhat, Assam (India)

Moreover, aerosols had influenced the reduction of light under normal light (3-10\%) merely as compared to shade condition (30$40 \%$ ). There was about $10 \%$ more reduction of light intensity by the reduced aerosol than the oxidised aerosol under shade condition. The aerosols might have assimilated by nitrogen reduction enzymes (i.e. NR \& NiR) under normal light condition, and was lesser available for interrupting the growing environment. Under the shade condition, more was the light reduction, lesser was the photon flux density of the crop under aerosol treated plants as compared to the control. In nature, atmospheric aerosols directly reduce the amount of solar radiation by scattering and absorbing light as it passes through the atmosphere. Anthropogenic aerosols can reduce solar radiation by as much as $30 \%$ on clear days in the agricultural area. ${ }^{27,}{ }^{28}$ In addition to reduction of the total amount of radiation, aerosol light scattering also tends to increase the fraction of radiation which is diffuse.

Diffuse fractions exist as high as $0.5-0.7$ on cloudless days in areas with high aerosol loadings. ${ }^{29}$ Aerosols also alter the amount of solar irradiance incident on the earth's surface by modifying the albedo, frequency, and lifetime of clouds. ${ }^{30}$

Specific leaf weight (SLW) in wheat was affected by both light and aerosol treatments. In general, SLW was $23.06 \%$ lower under shade than normal light conditions. The aerosol enhanced SLW in wheat. There were $15.55 \%$ and $52.50 \%$ higher SLW in plants treated with the reduced $\left(\mathrm{NH}_{4} \mathrm{Cl}\right)$ and oxidised $\left(\mathrm{NaNO}_{2}\right)$ aerosols respectively in comparison to control plants (Figure 1). Thin leaves are low in SLW and said to be characteristics of varieties suitable for low light intensities. ${ }^{31}$ Similar findings were also presented by Singh, ${ }^{32}$ who
Submit your Article | www.ologyjournals.com/submit-article PP Press $f$ in $y$ rifio
Citation: Bharali B, Chack S. Impacts of aerosols of oxidized and reduced nitrogen along with light regime, physiological drought and substratum types on wheat (Triticum aestivum L.) crop. Adv Agr Environ Sci. (20 I8); I ( ): 40-47. DOI: 10.3088 I/aaeoa.00007 
reported that low light induced by artificial shade (50\% of normal sunlight) from

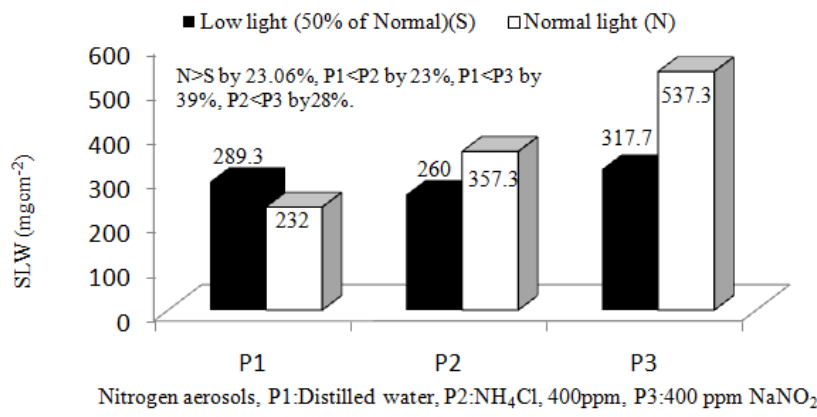

Figure I Effects of light and nitrogen aerosols on Specific leaf weight (SLW) of Ankur omkar wheat variety.

40 days after planting to harvest decreased SLW. It is opined that under low light condition SLW is reduced..$^{33}$ The aerosol might have rectified the low light effects by increasing the $\mathrm{N}$ input for chlorophyll synthesis, and help in adapting the enriched aerosol environment.

The low light singly or together with the aerosols reduced the quantum of yield attributes in wheat crop. Spike weight was significantly affected by the light regimes. The shaded plants had $45.8 \%$ lower spike weight than the plants under normal conditions. The aerosols did not affect significantly the spike weight (Figure 2). In a study in rice, Basu et al. (1985) also agreed with the present results, and confirmed that $50 \%$ light intensity during tillering to flowering stage of growth reduce the average grain yield. The reduction in yield is mostly through decrease in number of panicles and grains per unit area. SEDiff. $( \pm): 3.41, \mathrm{LSD}(0.05): 7.87$ for Light, $\mathrm{S}<\mathrm{N}$ by $46 \%, \mathrm{P} 1<\mathrm{P} 2$ by
$23 \%, \mathrm{P} 1<\mathrm{P} 3$ by $16.5 \%, \mathrm{P} 2>\mathrm{P} 3$ by $35.7 \%$

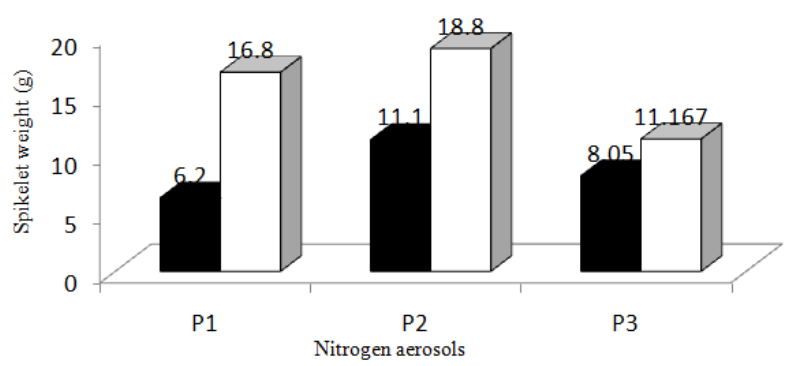

Nitrogen aerosols, P1:Distilled water, $\mathrm{P} 2: 400 \mathrm{ppm} \mathrm{NH} \mathrm{NH}_{4} \mathrm{Cl}$, P3:400 ppm NaNO${ }_{2}$

Figure2 Effects of light and $\mathrm{N}$-aerosols on spikelet weight of Ankur omkar wheat varietty.

Economic yield (Figure 3) was reduced by $47.98 \%$ under shade than Non-shade condition. There were also reductions in economic yield by Ammonium Chloride and Sodium nitrite by $31.97 \%$ and $30.12 \%$ respectively as compared to control. The reduced aerosol lessened economic yield than the oxidised aerosol by $2.65 \%$. Biological yield (Figure 4) was reduced by $47 \%$ under shade than Non-shade condition. Ammonium Chloride (30.67\%) and Sodium nitrite (27.57\%) also reduced biological yield as compared to control. The oxidised aerosol lessened $27 \%$ of biological yield over the reduced aerosol. Yields are progressively reduced with low light intensity appearing in succession at different growth phases. ${ }^{35}$

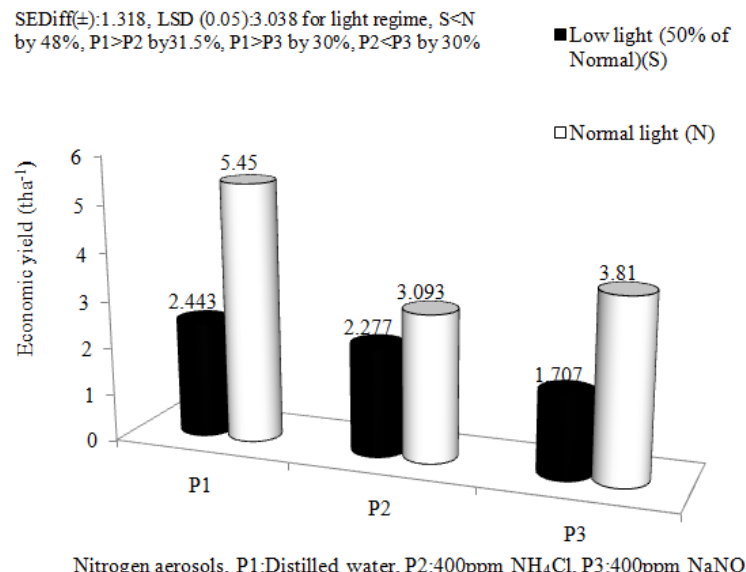

Figure 3 Effects of light and $\mathrm{N}$-aerosols on Economic yield of Onkur omkar wheat variety.

SEDiff(国):1.92, LSD(0.05):4.43 for Light regime. $S<\mathrm{N}$ by $47 \%$

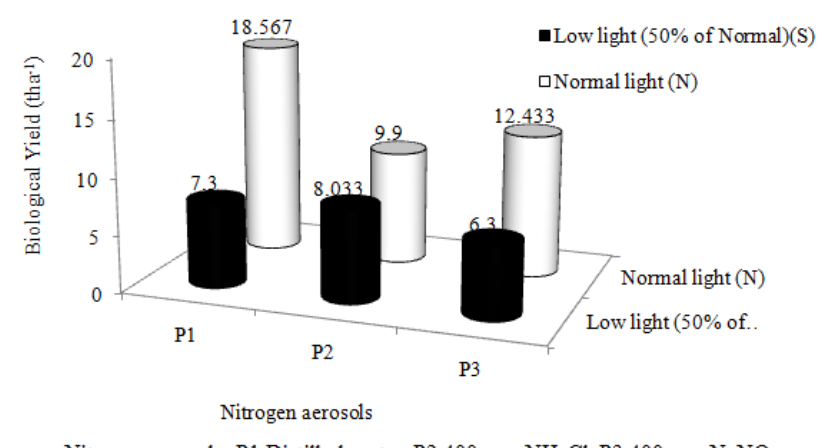

Nitrogen aerosols, P1:Distilled water, $\mathrm{P} 2: 400 \mathrm{ppm} \mathrm{NH}_{4} \mathrm{Cl}, \mathrm{P} 3: 400 \mathrm{ppm} \mathrm{NaNO}_{2}$

Figure 4 Effects of light regime and $\mathrm{N}$-aerosols on biological yield of Ankur omkar wheat variety.

There are differential responses of rice varieties on total dry matter, panicle number and grain yield under shade. Similarly, Yoshida ${ }^{12}$ confirmed the result, and indicated a strong positive correlation between grain yield and solar radiation during the last 30 days of crop growth. Thus, the present work has established that solar radiation from Panicle initiation to harvest is essential as the sink size (spikelet number) is determined by the light intensity before flowering and its proper filling by the incident light after flowering.

In the recent past, it was reported ${ }^{18,19}$ that Cell membrane stability in cereals is lowered by both $\mathrm{NH}_{4} \mathrm{Cl}$ and $\mathrm{NaNO}_{2}$. It was also stated that the rate of Lipid Peroxidase activity in cell membrane of wheat crop is increased by $\mathrm{NH}_{4} \mathrm{Cl}$ and $\mathrm{NaNO}_{2}$. The former depleted the cations from the membrane directly, and the later caused peroxidation of lipids present in the membrane. The oxides of nitrogen following the lipid breakdown in membrane cause cellular plasmolysis. ${ }^{4}$ Apart from uncoupling electron transport chain in chloroplast, ${ }^{9}$ ammonia reduces cations viz., calcium, magnesium, and potassium. ${ }^{38}$

Light treatments had significant effects on test weight of wheat crop. Shading reduced $20.29 \%$ higher test weight than under the normal light condition. The aerosols could not bring significant effects on the test weight (Figure 5). Oxidised aerosol brought down test 
weight by about $9-10 \%$ as compared to the reduced aerosol and the control. However, positive effects of the aerosols were found under normal light condition, and low light further suppressed the nitrogen assimilation and physiological growth of wheat crop. Venkateswarulu et al. ${ }^{37}$ were in agreement with this result that cultivar possessing a higher proportion of high density (HD) grains would be advantageous even under low light.

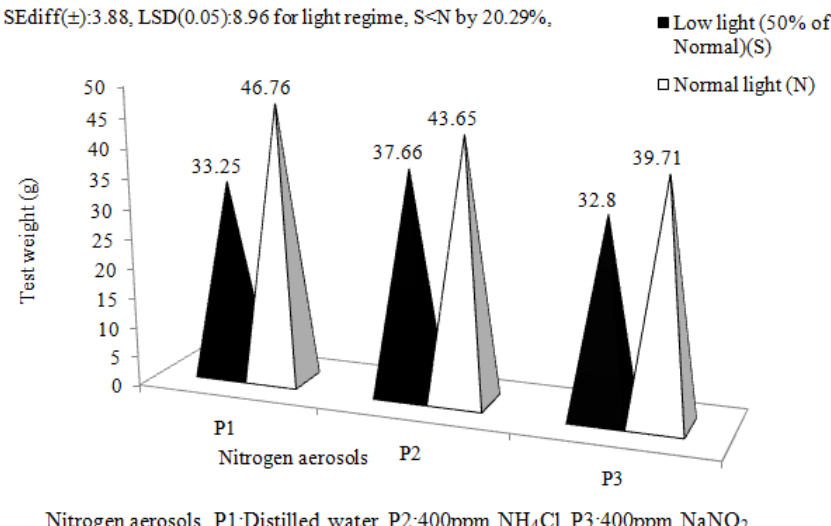

Figure 5 Effects of light regime and $\mathrm{N}$-aerosols on Test weight of Ankur omkar wheat variety.

SEdiff( \pm ):3.88, $\operatorname{LSD}(0.05): 8.96$ for light regime, $S<N$ by $20.29 \%$,

Nitrogen aerosols, $\mathrm{PI}$ :Distilled water, $\mathrm{P2}: 400 \mathrm{ppm} \mathrm{NH} \mathrm{N}_{4} \mathrm{Cl}, \mathrm{P3}: 400 \mathrm{ppm} \mathrm{NaNO}$.

Pierson and Elliott ${ }^{39}$ reported that there were differences in reduction of nitrite only at low light levels and high nitrite concentration.

Grain sugar was significantly reduced $(\approx 38 \%)$ by low light as compared to normal light (Figure 6). Low light intensity during crop growth results in accumulation of fructose 2-6-biphosphate, which modulates the key enzymes of sucrose biosynthesis, and then aids regulates of carbon flow under conditions of limited photosynthesis. ${ }^{40}$ In rice, low light reduces total sugars, mostly non reducing sugars and starch in all plant parts. ${ }^{30}$ A reduction in light by $50 \%$ or more, does impair translocation of carbohydrates to the developing sinks. ${ }^{41}$

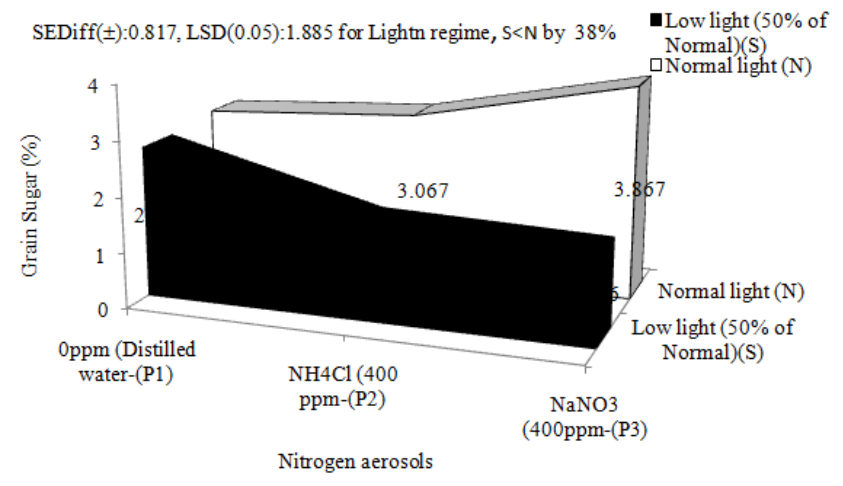

Nitrogen aerosols, P1:Distilled water, P2:400ppm NH 4 Cl, P3:400ppm $\mathrm{NaNO}_{2}$

Figure 6 Effects of light and Nitrogen aerosols on Grain sugar of Ankur omkar wheat variety.

In the second experiment, the plants were subjected to desiccation by Poly ethylene Glycol (PEG) sprays on foliages one week prior to the aerosol applications. The aerosols showed negative impacts on the physiology of wheat crop during physiological drought condition. Relative leaf water content (RLWC) in wheat was lowered by physiological drought and aerosol significantly. The reduced and oxidised aerosols lessened RLWC by $21.20 \%$ and $30.74 \%$ respectively. RLWC was $12.1 \%$ higher in plants treated with the oxidised aerosol than the reduced aerosol treated ones (Figure7a). Water deficit stress results in a considerable decline $(>50 \%)$ in RLWC. ${ }^{42,43}$ RLWC had been considered as a better indicator for water stress on plants, because RLWC through its relation to cell volume reflects the balance between water supply to the leaf and transpiration rate. ${ }^{44}$

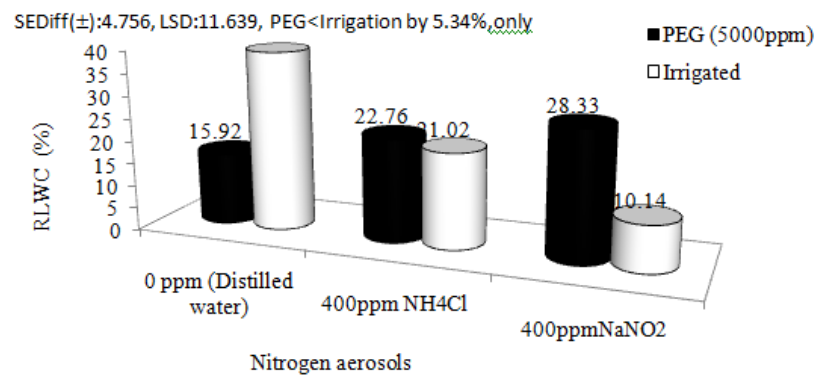

Figure7(a) Relative Leaf Water Conmtent (RLWC) in Ankur Omkar wheat variety.

PEG treatment restricted nitrogen mobilization and accumulated more proline derived from the nitrogen present in reduced and oxidised aerosols. The oxidised aerosol had produced $6.93 \%$ more proline than the reduced aerosol treatment (Figure 7b). Under water stress, accumulated proline might act as a compatible solute regulating and reducing water loss from the plant cell during water deficit. ${ }^{45}$ It plays an important role in osmosis balance. ${ }^{46}$ Proline accumulates under stress also supplies energy for survivor and growth, and thereby helps the plants to tolerate stress condition. ${ }^{47}$

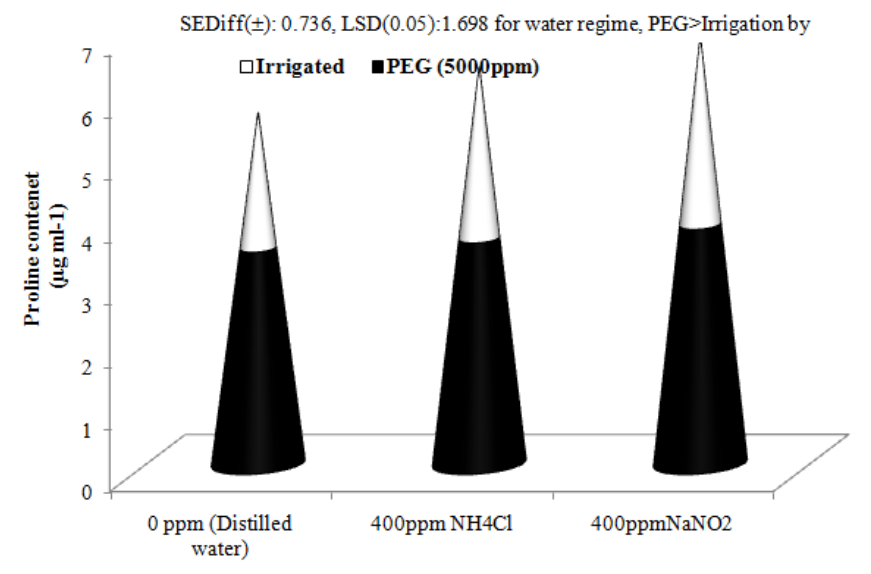

Figure 7(b) Leaf proline of Ankur omkar wheat variety.

The test weight of 1000 grains of the wheat crop varied significantly due to the physiological drought condition. (Figure 8a). There was $9.79 \%$ reduction in test weight in physiological drought condition as compared to the normal one. The effects of aerosols on test weight were not significant. However, there were increases of test weight (by $6.11 \%$ ) due to reduced and oxidized aerosols. The difference in test weight is mainly due to differences in rate of photosynthesis and dry matter partitioning to developing grains. Venkateswarulu and Vispere ${ }^{37}$ reported that translocation of assimilates to the panicle during post flowering is a determinant of economic yield.

Harvest index (HI) of the rice crop varied significantly due to the physiological drought condition (Figure 8b). There was $4.42 \%$ 
reduction in $\mathrm{HI}$ in physiological drought condition as compared to the normal plants. The effects of aerosols on HI were not significant. However, $\mathrm{NaNO}_{2}$ reduced $\mathrm{HI}$ by $5.22 \%$ as compared to $\mathrm{NH}_{4} \mathrm{Cl}$ at the same concentration $(400 \mathrm{ppm})$. There is higher $\mathrm{HI}$ in well irrigated genotypes compared to that of the genotypes which were grown under water stress condition. Water stress at flowering and grain filling produces lower $\mathrm{HI}$ than water stress at tillering stage. ${ }^{48}$

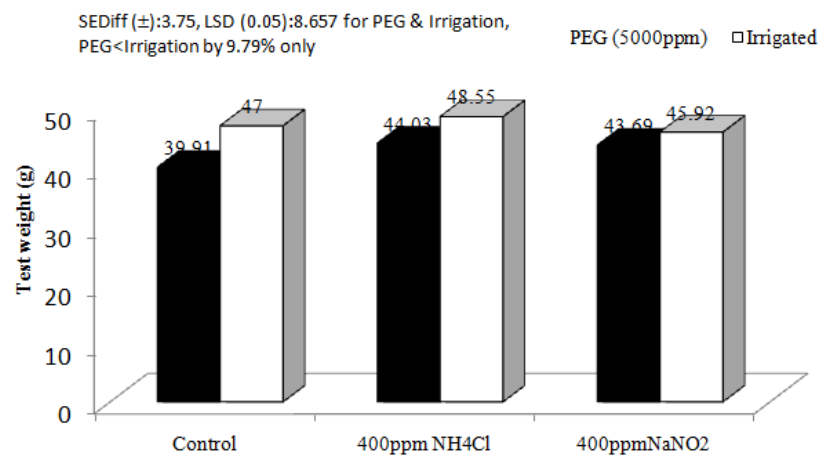

Figure 8 (a) Test weight of Ankur Omkar wheat variety.

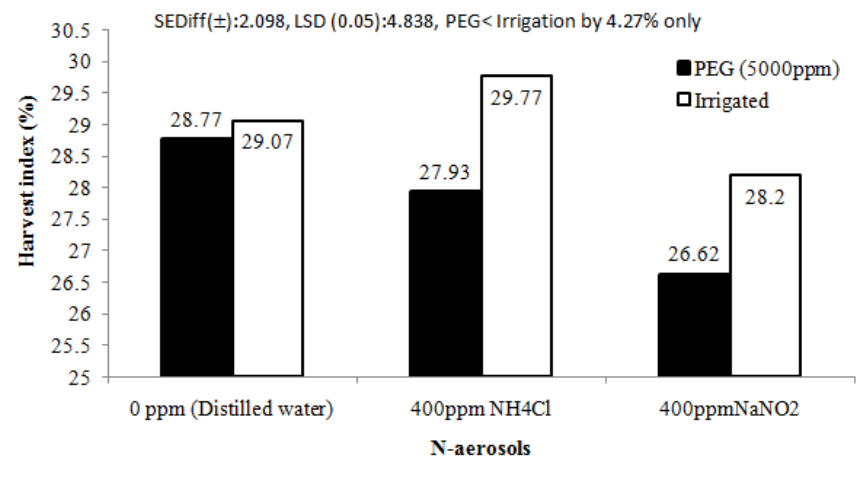

Figure 8(b) Harvest inde of Ankur Omkar wheat variety.

In the third experiment, the substratum had significant effects on effective tillers (Figure 9a). There were $29.21 \%$ and $40.05 \%$ increases in effective tillers in acid Soil with 5t/ha FYM (pH5.03) than in acid soil with acid soil with 10/ha FYM (pH 5.92) and acid soil with 10t/ ha FYM + lime @0.5t/ha (pH6.46). There was also 18.09\% increase in effective tillers in acid soil with 10/ha FYM (pH 5.92) than acid soil with 10t/ha FYM + lime @0.5t/ha (pH6.46). The aerosols had no significant effects on the effective tillers. Rather, the reduced (7.37\%) and oxidized aerosols (7.72\%) increased the effective tillers of wheat crop. This might be the due to some plausible neutralizing effects of the substratum on the aerosols.

The aerosols had significant effects on spikelet number of wheat crop (Figure $9 \mathrm{~b}$ ). In general, there were $5.49 \%$ and $8.89 \%$ increases in spikelet number in the reduced and oxidized aerosols as compared to the control. The reduced aerosol produced only 3.59\% higher spikelet number than in the oxidized aerosol. The substratum couldn't bring about any significant change in spikelet number. However, plants on acid Soil with 5t/ha FYM (pH5.03), produced 5.21\% higher spikelet number than in plants on acid soil with 10/ha FYM (pH 5.92). Similarly, acid soil with 10/ha FYM (pH 5.92) increased spikelet number by about $5.54 \%$ as compared to acid soil with $10 \mathrm{t} / \mathrm{ha}$ FYM+ lime@0.5t/ha (pH6.46). The crop might not get sufficient nutritional support from the varying levels of substrata to nullify the effects of the aerosols.

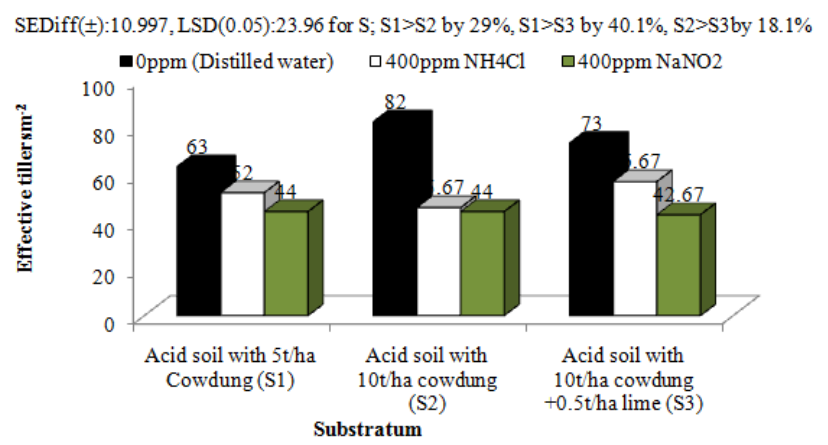

Figure 9 (a) Effects of substratum and $\mathrm{N}$-aerosols on effective tillers of wheat.

$\operatorname{SEDiff}( \pm): 2.102, \operatorname{LSD}(0.05): 4.628$ for P. P1>P2 by $5.49 \%, \mathrm{P} 1<\mathrm{P} 3$ by $8.89 \%, \mathrm{P} 3<\mathrm{P} 2$ by $3.59 \%$

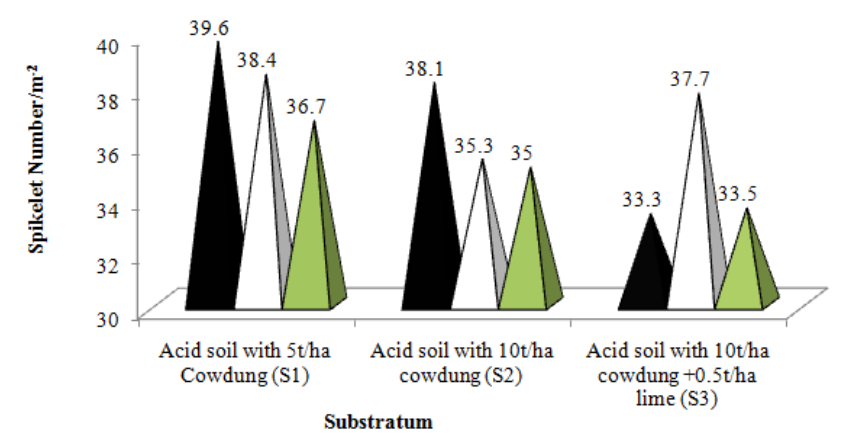

Figure 9(b) Effects of substratum and $\mathrm{N}$-aerosols on Spikelet of Ankur omkar wheat variety.

Data on Harvest Index (HI) of wheat crop (Variety, Ankur Omkar) varied significantly due to the substratum as well as the pollutants (Table 2a). Acid Soil with 5t/ha FYM (pH5.03) expressed 18.264\% and $3.471 \%$ increases in HI on Acid soil with 10/ha FYM (pH 5.92) as well as Acid soil with 10t/ha FYM+lime@0.5t/ha (pH6.46) respectively. The crop grown on Acid soil with 10/ha FYM (pH 5.92) showed $15.32 \%$ higher HI than on Acid soil with 10t/ha FYM+lime (a) $0.5 \mathrm{t} / \mathrm{ha}$ (pH6.46). The aerosols also brought significant changes on HI of the crop. The reduced aerosol and the oxidized aerosol decreased $\mathrm{HI}$ by $8.29 \%, 12.97 \%$ ) respectively than the production of $\mathrm{HI}$ in control plants. In this instance, the reduced aerosol acted as an acidifying agent, and was $20.18 \%$ more deleterious than the oxidized aerosol.

Spike weight in wheat varied significantly due to the interaction of aerosol and the substrata (Table 2b). A little change in spike weight was brought about by the aerosols independently on wheat crop upon acid soil with 5t/ha FYM (pH 5.03) as well as acid soil with10t/ ha FYM (pH 5.92). In wheat crop grown on acid soil with 10t/ha FYM +lime@0.5t/ha (pH 6.46), the reduced aerosol increased spike weight by $23.37 \%$, and the oxidised aerosol increased it by $13.75 \%$ as compared to the control distilled water treatment.

Soil amended with higher dose (10t/ha) of FYM further exerted negative influence to the crop due to increasing acidity of soil. Acid soil amended with lime $\left(\mathrm{Ca}^{2+}\right)$ ameliorated the effects of acidity on several yield parameters of wheat crop. In the present investigation, 
the hypothesis that oxidized $\left(\mathrm{NO}_{2}\right)$ and reduced $\left(\mathrm{NH}_{3}\right)$ nitrogen impact on wheat, which may be ameliorated by supplying $\mathrm{Ca}^{2+}$ richer substratum, was tested. The importance of a calcareous substratum in reducing the damaging effects of nitrogenous pollutants was also demonstrated indirectly by Morecroft et al ${ }^{49}$ Cultivation of plants in contact with artificial substrata leads to significant changes in their cation contents. On the calcareous substratum, the exchangeable $\mathrm{Ca}^{2+}$ concentration is boosted by a factor of six, whereas exchangeable and intracellular $\mathrm{Mg}^{2+}$ concentration is lowered. The reciprocal relationship between these two ions has been demonstrated in several studies, apparently the result of competitive displacement on cell wall cation exchanger. ${ }^{50,14,18,19}$

Table 2 Effects of substratum and $\mathrm{N}$-aerosols on harvest index $(\mathrm{HI})$ and Spike weight of Ankur omkar wheat variety

\begin{tabular}{|c|c|c|c|c|c|c|}
\hline \multirow{2}{*}{$\begin{array}{l}\text { Parameters } \\
\text { Aerosols (A) } \\
\text { Substrata (S) }\end{array}$} & \multicolumn{3}{|c|}{ (a) HI:Harvest index (\%) } & $(\mathrm{b}$ & \multicolumn{2}{|c|}{ Five Spike weight (g) } \\
\hline & $\begin{array}{l}\text { Control } \\
\text { (Oppm) }\end{array}$ & $\begin{array}{l}\mathrm{NH}_{4} \mathrm{Cl} \\
(400 \mathrm{ppm})\end{array}$ & $\begin{array}{l}\mathrm{NaNO}_{2} \\
(400 \mathrm{ppm})\end{array}$ & $\begin{array}{l}\text { Control } \\
\text { (Oppm) }\end{array}$ & $\begin{array}{l}\mathrm{NH}_{4} \mathrm{Cl} \\
(400 \mathrm{ppm})\end{array}$ & $\begin{array}{l}\mathrm{NaNO}_{2} \\
(400 \mathrm{ppm})\end{array}$ \\
\hline $\begin{array}{l}\text { Acid Soil with } 5 t / h a \text { FYM } \\
(\mathrm{pH} 5.03)\end{array}$ & 28.11 & 24.68 & 30.16 & 18.65 & 20.5 & 16.0 \\
\hline $\begin{array}{l}\text { Acid soil with } 10 / \text { ha FYM (pH } \\
5.92)\end{array}$ & 23.05 & 17.77 & 26.97 & 18.5 & 17.35 & 19.75 \\
\hline \multirow[t]{2}{*}{$\begin{array}{l}\text { Acid soil with 10t/ha FYM+lime } \\
@ 0.5 \mathrm{t} / \mathrm{ha}(\mathrm{pH} 6.46)\end{array}$} & 24.11 & 26.59 & 29.37 & 17.25 & 23.75 & 20.00 \\
\hline & SEdiff. $( \pm)$ & $\operatorname{LSD}(0.05)$ & & SEdiff. $( \pm)$ & $\operatorname{LSD}(0.05)$ & \\
\hline (A) & 3.43 & 7.48 & & - & ns & \\
\hline (S) & 2.847 & 6.627 & & - & ns & \\
\hline$(A) \times(S)$ & - & ns & & 1.45 & 3.286 & \\
\hline
\end{tabular}

Source: Field experiment, 2012 at Assam Agricultural University, Jorhat, Assam (India)

In plant cells, calcium is one of the integral components of plasma membrane, where it helps maintain stability. ${ }^{51}$ Calcium ions binds with modulator proteins e.g. calmodulin, ${ }^{52}$ and serves as chemical signaling to equip the plant and resist external stresses. ${ }^{53}$ These possibilities have not been explored meticulously in the present studies. There is evidence that the light activated absorption of $\mathrm{Ca}^{2+}$ into the chloroplasts and mitochondria regulates the enzyme NAD kinase and NADH dehydrogenase activity, respectively, which are involved in the energy metabolism (e.g. formation of NADPH) of pyruvate production..$^{54,55,52}$ The yield attributes are related to the assimilation of carbon (photosynthesis) triggered by the several key enzymes modulated by $\mathrm{Ca}^{2+}$. Such an effect is plausibly also stimulated the yield attributes when the crop was grown on acid soil amended with lime. In acid mineral soils, iron in the form of $\mathrm{Fe}^{3+}$, is abundant and highly mobile in acid conditions. Although iron is an essential micronutrient, it has deleterious effects under higher concentration situations. Because, iron in the form ferritin of ferredoxin catalyses the formation of the highly damaging hydroxyl radical $\left(\mathrm{OH}^{-}\right)$from super oxide, or its dismuted product $\mathrm{H}_{2} \mathrm{O}_{2}$. In general, $\mathrm{OH}^{-}$initiates the peroxidative breakdown of lipids, ${ }^{56,57}$ which leads to loss of membrane integrity. In elevated availabilities of these two cations under contrasting conditions (i.e. higher $\mathrm{pH} \&$ lower $\mathrm{pH}$ ), there might be some mutually antagonistic effects on plant cells, especially those under aerosols stress. The extent to which the metal ions derived from the substratum detoxify the nitrogenous aerosols passively or actively in wheat remains an important future research thrust.

\section{Conclusion and recommendation}

A positive effect of the Nitrogen $(\mathrm{N})$-aerosols was found under normal light condition, and low light further suppressed the nitrogen assimilation and physiological growth of wheat crop. During the physiological drought induced condition (Desiccation) by PEG-6000, the $\mathrm{N}$-aerosols showed negative impacts on the physiology of wheat crop. In wheat, the reduced aerosol acted as an acidifying agent, and found deleterious to the physiology of wheat crop. Soil amended with higher dose (10t/ha) of FYM further exerted negative influence to the crop. Acid soil amended with lime (supply of $\mathrm{Ca}^{2+}$ ) ameliorates the negative impacts of the aerosols on yield attributes of wheat crop.

\section{Acknowledgement}

The authors express deep sense of gratitude to the Ministry of Environment \& Forests, Govt. of India for pecuniary assistance to conduct the research. The field and laboratory facilities provided generously by from Assam Agricultural University are also fully accredited.

\section{References}

1. Zeevaart AZ. Some effects of fumigating plants for short periods with NO2. Environmental Pollution. 1976;11(2):97-108.

2. Runge M. Physiology and ecology of nutrition. Encyclopaedia of Plant Physiology (new seris). 1983;12:163-200.

3. Darrall NM. The effects of air pollutants on physiological processes in plants. Plant, Cell and Environment. 1989;12:1-30.

4. Pryor WA et al. $\mathrm{NO}_{2}$ reaction: initiation of lipid peroxidates and the production of nitrous acid. Science. 1984;214:435-437.

5. Mohan M, Kumar S. Review of Acid rain potential in India: Future threats and remedial measures. Current science. 1998:75(6):579-593.

6. McClean CJ, Leon van den Berg, Mike Ashmore, et al. Atmospheric nitrogen deposition explains patterns of plant species loss. Global Change Biology. 2011;17(9):2882-2892. 
7. Mehree I, Mohr H. Ammonium toxicity:description of the syndrome in Sinapsis alba and the search for its causation. Physiologia plantarum. 1989;77:545-554.

8. Sutton MA, Moncrieff JB, Fowler D. Deposition of atmospheric ammonia to moorlands. Environmental Pollution. 1992;75(1):15-24.

9. Lilley RM, Fitzgerald MP, Rienits KG, et al. Criteria of intactness and the photosynthetic activity of spinach chloroplast preparations. New Phytologist. 1975;75:1-10.

10. Marschner H, Haussling M, George E. Ammonium and nitrate uptake rates and rhizosphere $\mathrm{pH}$ in non micorrhizal roots of Norway spruce (Picea abies L., Karst). Trees. 1991;5(1):14-21.

11. Boxman AW, Krabbendam H, Bellemakers MJ, et al. Effects of ammonium and aluminium on the development and nutrition of Pinus nigra in hydroculture. Environ Pollut. 1991;73(2):119-136.

12. Yoshida S. Tropical Climate and its influence on rice. Research Paper Series. 1978;20:1-25.

13. Prasad PVV, Staggenborg SA. Impacts of drought and/or heat stress on physiological, developmental, growth, and yield processes of crop plants. 2008;301-355.

14. Bharali B, Bates JW. Soil cations influence Bryophyte susceptibility to bisulphyte. Annals of Botany. 2002;90:337-343.

15. Sarma P, Bharali B. Effects of calcium on physiology of rice under iron toxic condition. Indian Journal of Plant and Soil. 2015;2(2):42-47.

16. Begum M, Bharali B. Calcium ameliorates Bronzing in rice (Oryza sativa L.) under field condition. Indian Journal of Plant and Soil. 2016;3(1):13-22.

17. Bharali B, Bates JW. Influences of extracellular calcium and iron on membrane sensitivity to bisulphiote in the mosses Pleurozium schreber and Rhytidiadelphus triquetrus. Journal of Bryology. 2004;26(1):53-59.

18. Bharali B, Haloi B, Chutia J, et al. Susceptibility of some wheat (Triticum aestivum L.) varieties to aerosols of oxidised and reduced Nitrogen. Advances in Crop Science and Technology. 2015a;3(4):1-8.

19. Bharali B. et al., Role of oxidised and reduced nitrogen aerosols on productivity of rice (Oryza sativa L.) Crop. International Journal of Environment and Agricultural Research. 2015b;1(1):1-15.

20. Singh D. Studies on photosynthesis, growth, development and yield of wheat genotype under different sowing dates. 1988;124.

21. Dhopte AM, Livera-Munoz M. Useful techniques for plant scientists. Publication of forum for Plant Physiologists, R.D.C College, Akola, India. 1989.

22. Clayton RK. Light and Living Matter. Volume 1. The Physical Part. McGraw-Hill Book Company, New York. 1970.

23. Yoshida S. Measurement of leaf area and leaf area index. Laboratory Manual for Physiological Studies of Rice. 1976;69-71.

24. Martin MA, Jarvis H Brown, Hayden Ferguson. Leaf water potential, relative water content and diffusive resistance as screening techniques for drought resistance in barley. Agron J. 1989;21:100-105.

25. Bates LS, WaldrenI RP, Teare ID. Rapid determination of free proline in water stress studies. Plant Soil. 1973;39(1):205-207.

26. Crawley Michael J. Methods in Ecology: GLIM for Ecologists. Oxford Blackwell Scientific publications, London. 1985.

27. Chameides WL. Case Study of the effects of atmospheric R. Agricultural Systems 89. 2006;390-413.
28. Xu J, Mike Bergin, Roby Greenwald, et al. Direct aerosol radiative forcing in the Yangtze delta region of China: Observation and mode estimation. J Geophys Res. 2003;108:4060-4071.

29. Lorente J, Redañ A, De Cabo X. Influence of urban aerosol on spectral solar irradiance. J Appl Meteorol. 1994;33:406-415.

30. Hobbs PV. Aerosol-Cloud Interactions. In: Hobbs, PV (Ed.), AerosolCloud-Climate Interactions. Academic Press, San Diego. 1993:33-75.

31. Sahu G. Screening for shade tolerance in rice seedlings. In: Rice Rese Newsl. 1984;9(3):25-26.

32. Singh VP. Annual report, 48, A research project under National Fellow award, CRRI, Cuttack. 1985.

33. Janardhan KV, Murty KS. Effect of low light during vegetative stage on photosynthesis and growth attributes in rice. Indian Journal of Pant Physiology. 1980;23(2):156-162.

34. Basu Choudhury. Effect of low light intensity on yield of late duration tal Indica rice varieties. Oryza.1985;22:243-245.

35. Venkateswrulu B. Influence of light intensity on growth and productivity of rice (Oryza sativa L.) Plant Soil. 1977;47:712-719.

36. Venkateswrulu B, Srinivasan TE. Influence of light intensity on growth, productivity in relation to population pressure and varietal reaction in irrigated rice (Oryza sativa L.) Indian $J$ of Plant physiol. 1978;21(2):162-170

37. Venkateswrulu B, Visperas MM. Source - sink relationship in crop plant International Rice research Paper Series. 1987;125:1-19.

38. Boxman AW, Krabbendam H, Bellemakers MJ, et al. Effects of ammonium and aluminium on the development and nutrition of Pinus nigra in hydroculture. Environ Pollut. 1991;73(2):119-136.

39. Peirson D, Elliot JR. Effects of nitrite and bicarbonate on nitrite utilization in leaf of bush bean (Phaseolus vulgaries). Journal of Plant Physiology. 1988;133(4):425-429.

40. Reddy AR, Das R. Modulation of sucrose content by fructose 2,6, biphosphate during photosynthesis in rice leaves growing at different light intensities. Journal of Experimental Botany. 1987;38(190):828-833.

41. Murty KS. Breeding rice varieties for higher physiological efficiency. Indian J. Genet 34 A. 1974;995-1000.

42. Khan HR, W Link, Hocking TJH, et al. Evaluation of physiological traits for improving drought tolerance in faba bean (Vicia faba L.) Plant and Soil. 2007;292:205-217.

43. Das K. Evaluation of drought resistance characteristics of upland rice cultivars. Oryza. 2000;37:4-6.

44. Sinclair IR, Ludlow MM. Who thought plant thermodynamics? The unfulfilled potential of water potential. Aust J Pl Physiol. 1985;12:213-217

45. Yokota, A. Physiology and molecular biology of stress tolerance in plants. In: Madhavarao, Raghavendra K. Janardhanreddy K (eds.). Springer. 2006:15-40.

46. Fedina IS, GeorgievaI K, Grigorova I. Light - dark changes in proline content of barley leaves under salt stress. Inst Plant Physiol. 2002;45(1):59-63.

47. Kumar RR, Krishna Karajol, Naik GR. Effect of polyethylene glycol induced water stress on physiological and biochemical responses in pigeon pea (Cajanus cajan L. Mill sp.). Recent Res Sci Tech. 2011;3(1):148-152.

48. Sharma KD, Pannu RK, Tyagi PK. et al. Effect of moisture stress on plant water relations and yield of different wheat genotypes. Indian J Plant Physiol. 2003;8(1):99-102. 
49. Morecroft MD, Sellers EK, Lee JA. An experimental investigation into the effects of atmospheric nitrogen deposition on two semi-natural grasslands. Journal of Ecology. 1994;82:473-483.

50. Bates JW. Retention of added K, Ca, and $\mathrm{P}$ by Pseudoscleropodium purum growing under an oak canopy. Journal of Bryology. 1989;15(3):589-605.

51. Legge RL, Thompson JE, Baker JE. et al. The effect of calcium on the fluidity of phase properties of microsomal membranes isolated from postclimacteric golden delicious apples. Plant and Cell Physiology. 1982;23(2):161-169.

52. Dieter P. Calmodulin and calmodulin-mediated processes in plants. Plant, Cell and Environment. 1984;7(6):371-380.

53. Person $\mathrm{S}$. et al. The $\mathrm{Ca} 2+$ status of the endoplasmic reticulum is altered by induction of calreticulin expression in transgenic plants. Plant Physiol. 2001;126(3):1092-1104.
54. Moore AL, Cottingham IR. Characteristics of the higher plants respiratory chain. In: Metals and nutrients, uptake and utilization by plants, Phytochemical Society of Europe. Symposia No. 21. Ed. Robb, D.A. and Pierpoint, W.S. pp. 169-204, Academic Press, London. 1983.

55. Moore AL, Rich RR. The bioenergetics of plant mitochondria. Trends in Biochemical Sciences. 1980;5(11):284-288.

56. Price AH, Hendry GAF. Iron catalysed oxygen radical formation and its possible contribution to drought damage in nine native grasses and three cereals. Plant Cell and Environment. 1991;14:477-848.

57. Legge AH, Krupa SV. Effects of sulphur dioxide. In: Bell JNB, Treshow M, eds. Air pollution and plant life, $2^{\text {nd }}$ edn. Chichester: John Wiley, USA. $2002 ; 135-162$. 